ISSN: 2303-1514 | E-ISSN: 2598-5949

DOI : http://dx.doi.org/10.33578/jpfkip.v9i4.7986

https://primary.ejournal.unri.ac.id/index.php/JPFKIP

\title{
THE EFFECT OF PARENTS ROLE TOWARDS THEMATIC LEARNING OUTCOMES OF CLASS V STUDENTS
}

\author{
Andreas Au Hurit ${ }^{1}$, Nur Eka Lestari ${ }^{2}$, Agus Kichi Hermansyah ${ }^{3}$ \\ 1,2,3 Universitas Musamus, Merauke, Indonesia \\ aguskichi@unmus.ac.id
}

\begin{abstract}
PENGARUH PERAN ORANG TUA TERHADAP HASIL BELAJAR TEMATIK SISWA KELAS V
\end{abstract}

\begin{abstract}
ARTICLE INFO
Submitted:

20 Juli 2020

$20^{\text {th }}$ July 2020

\section{ABSTRACT}

Abstract: The role of parents is one of the factors that affect students' learning outcomes so the purpose of this study is to determine the effect of the role of parents on students thematic learning outcomes of class $V$ of MI Al-Ma'arif Merauke. This research was a quantitative correlation and expose facto research conducted at MI Al-Ma'arif Merauke. The subjects of this study were students of class V B MI AL-Ma'arif totaling 32 students. Data collection techniques used were questionnaires and documentation. The instruments used were questionnaire sheets and documents. While the data analysis techniques used were correlation test, hypothesis test $(t)$. Calculation of hypothesis testing used SPSS version 21 using the product moment correlation formula. The results showed that there was a relationship between the role of parents on students' thematic learning outcomes, this was indicated by the results of the correlation coefficient of $0.389>r_{\text {table }}$ of 0.349 and a significance level of $0.028<$ 0.05 with a low level of influence. $t$ test results revealed that the $t$ value of $2.310>t_{\text {table }} 2.042$ with a significance value of $0.028<0.05$ and the results of the coefficient of determination $\left(r^{2}\right)$ of $15,1 \%$, this shows there is an effect of the role of parents on the thematic learning outcomes of students.
\end{abstract}

Accepted:

27 Agustus 2020

$27^{\text {th }}$ August 2020

Published:

01 September 2020

$1^{\text {st }}$ September 2020

Keywords: thematic learning outcomes, role of parents, elementary school

Abstrak: Peran orang tua merupakan salah satu faktor yang mempengaruhi hasil belajar siswa sehingga tujuan penelitian ini adalah mengetahui pengaruh peran orang tua terhadap hasil belajar tematik siswa kelas V MI Al-Ma'arif Merauke. Penelitian ini merupakan penelitian kuantitatif korelasi dan expose facto yang dilaksanakan di MI Al-Ma'arif Merauke. Subjek penelitian ini adalah siswa kelas V B MI AL-Ma'arif berjumlah 32 siswa. Teknik pengumpulan data yang digunakan yaitu angket dan dokumentasi. Instrumen yang digunakan yaitu lembar angket dan dokumen. Teknik analisis data yang digunakan yaitu uji korelasi, uji hipotesis (t). Perhitungan pengujian hipotesis menggunakan bantuan program SPSS versi 21 menggunakan rumus korelasi product moment. Hasil penelitian menunjukan bahwa terdapat hubungan antara peran orang tua terhadap hasil belajar tematik siswa, hal ini ditunjukan dengan hasil koefisien korelasi $r_{\text {hitung }} 0.389>r_{\text {tabel }} 0.349$ dan taraf signifikansi 0.028 $<0.05$ dengan tingkat pengaruh rendah. Hasil uji $t$ diketahui nilai $t_{\text {hitung }} 2.310>t_{\text {tabel }} 2.042$ dengan nilai signifikansi sebesar $0.028<0.05$ dan hasil koefisien determinasi $\left(r^{2}\right)$ sebesar 15,1\%. Berdasarkan hasil penelitian tersebut dapat disimpulkan bahwa terdapat pengaruh peran orang tua terhadap hasil belajar tematik.

Kata kunci: hasil belajar tematik, peran orang tua, sekolah dasar

CITATION

Hurit, A.A., Lestari, N.E., \& Hermansyah, A.K. (2020). The Effect of Parents Role towards Thematic Learning Outcomes of Class V Students. Primary: Jurnal Pendidikan Guru Sekolah Dasar 9(4), 540-547. DOI: http://dx.doi.org/10.33578/jpfkip.v9i4.7986. 


\section{PENDAHULUAN}

Keluarga merupakan tempat seorang anak pertama kali berinteraksi sebagai makhluk sosial. Dalam lingkungan keluarga orang tua berperan penting dalam pembentukan karakter, kecerdasan anak, penanaman nilai, norma, dan budaya yang ada dalam masyarakat. Orang tua dapat dikatakan sebagai pusat pendidikan pertama bagi anak sebelum memperoleh pendidikan formal disekolah.

Orang tua sebagai pendidik pertama bagi anak maksudnya adalah dari orang tua, anak pertama kali menerima pendidikan (Hurit, \& Harmawati, 2019). Dengan demikian, bentuk pertama dari pendidikan terdapat dalam lingkungan keluarga. Orang tua dituntut untuk menjadi pendidik yang memberikan pengetahuan pada anak dan memberikan sikap serta keterampilan yang memadai, memimpin keluarga, mengatur kehidupannya, dan bertanggung jawab dalam kehidupan keluarga, baik yang bersifat jasmani maupun rohani (Fredy, Tembang, \& Purwanty, 2019).

Setiap orang tua tentu menginginkan yang terbaik untuk anaknya termasuk pendidikan dengan harapan anak kelak menjadi menusia dewasa yang mandiri, produktif, berakhlak dan berbudi pekerti. Orang tua akan mencarikan sekolah terbaik bagi anak dan berharap anak mendapatkan pendidikan yang baik dan hasil belajar yang memuaskan. Tetapi keberadaan anak di sekolah hanya beberapa jam saja jika dibandingkan dengan keberadaan anak di rumah. Sehingga orang tua memiliki pengaruh yang kuat dalam memberikan pendidikan terhadap anak. Memberikan teladan merupakan cara yang lebih efektif dari pada bahasa, karena hal tersebut dapat memberikan gambaran dan isyarat jelas yang dapat ditirukan.

Keterlibatan orang tua memberikan pengaruh terhadap proses belajar anak dan hasil beajar anak yang akan dicapai. Hasil penelitian Muchuchuti (2015: 25) menunjukkan bahwa keterlibatan orang tua dalam pendidikan anak dapat meningkatkan kepercayaan diri, minat, dan hasil belajar anak di sekolah. Selain itu peran orang tua dapat memberikan pengaruh baik bagi penilain guru kepada siswa. orang tua ikut memberikan peran dalam menentukan segala aktivitas di rumah untuk melengkapi programprogram pendidikan di sekolah dan membangun komonikasi yang baik antara orang tua dan pihak sekolah untuk mengetahui perkembangan anak.

Permasalahan umum yang dialami oleh orang tua dalam meberikan perhatian bagi anakanaknya banyak disebabkan oleh kesibukan bekerja mencari nafkah. Mereka memberi alasan bahwa tidak mempunyai waktu mendampingi anak-anaknya belajar dan membantu mengerjakan perkerjaan rumah. Orang tua menghabisi waktunya untuk bekerja dan tidak meluangkan waktu untuk memberikan bimbingan bagi anak-anaknya. Selain itu masalah sumber daya manusia orang tua yang menyebabkan kurangnya meraka untuk ikut serta meningkatkan hasil belajar anaknya.

Berdasarkan hasil pengamatan yang dilakukan di MI Al-Ma'arif pada 17 Januari 2019 sampai dengan 25 Maret 2019, diketahui bahwa dalam proses pembelajaran di sekolah siswa selalu bertanya jika materi tidak dapat dipahami dan pada umumnya siswa antusias mengerjakan tugas di sekolah atau pekerjaan rumah yang diberikan. Tetapi ada juga siswa yang kurang sungguhsungguh dalam belajar, membuat keributan dikelas dan tidak mengerjakan tugas-tugas yang berikan oleh guru. Siswa juga sering melanggar peraturan sekolah seperti tidak memakai sepatu, baju tidak dimasukan bagi laki-laki dan lupa membawa perlengkapan sekolah.

Setelah ditelusuri dengan bertanya kepada siswa dan berdasarkan pengamatan yang dilakukan oleh peneliti beberapa orang tua memiliki kesibukan yang cukup padat sehingga anak kurang mendapat perhatian dari orang tua. Meski demikian, ada orang tua yang telah memberi perhatian khusus terhadap anak sehingga melakukan berbagai macam cara agar anak semangat dan termotivasi untuk belajar.

Interaksi antara anak dan orang tua penting dalam proses belajar, dengan adanya interaksi yang baik antara orang tua dan anak maka kesulitan belajar dapat diminimalisir. Peran orang tua dapat mempengaruhi proses belajar tematik anak karena pembelajaran tematik berisi 5 mata pelajaran berbeda yang dimuat menjadi satu, maka anak perlu mendapat bimbingan khusus dirumah untuk 
membantu anak berkonsentrasi dalam belajar.

\section{KAJIAN TEORETIS \\ Peran Orang Tua}

Peran menurut Katz dan Kahn merupakan tindakan yang dilakukan berdasarkan karakter dan kedudukannya. Peran dilakukan jika seseorang menjalani tugas sesuai dengan kedudukan dan tanggung jawabnya (Purnamie, 2014:10). Kamus Oxford Dictionary mengartikan peran sebagai Actor's part; one'soor function yang memiliki arti tugas seseorang atau fungsi. Kemudian dapat simpulkan bahwa peran merupakan tugas atau tanggung jawab seseorang yang harus dijalankan sesuai dengan kedudukannya.

Orang tua berperan banyak dalam kehidupan anak termasuk peran dalam mendidik sehingga, orang tua dikatakan sebagai pendidik pertama dan utama bagi anak (Daradjat, 2004: 35). Orang tua sebagai pendidik pertama maksudnya adalah anak akan belajar segala sesuatu dimulai dari orang tua sehingga orang tua merupakan guru pertama bagi anak. Sedangkan, pendidik utama maksudnya adalah sebagai seorang anak yang dilahirkan dalam keadaan tidak berdaya anak membutuhkan orang lain untuk menggantungkan hidupnya dan orang tua merupakan tempat bergantung paling utama bagi anak.

\section{Macam-macam Peran Orang Tua}

Arifin (2012: 92) menyebutkan ada tiga peran orang tua yang berperan dalam prestasi belajar anak, yaitu: 1) Menyediakan kesempatan sebaik-baiknya kepada anak untuk menemukan minat, bakat, serta kecakapan-kecakapan lainnya serta mendorong anak agar

meminta bimbingan dan nasehat kepada guru, 2) Menyediakan informasi-informasi penting dan relevan yang sesuai dengan bakat dan minat anak, 3) Menyediakan fasilitas atau sarana belajar serta membantu kesulitan belajarnya.

\section{Indikator Peran Orang Tua}

Indikator ditetapkan peneliti untuk mendapatkan informasi peran orang tua terhadap pendidikan anak di sekolah ada 5 indikator yaitu: pertama, memberi bimbingan. Menurut Sukardi,
Ketut \& Kusumawati (2008: 2) bimbingan adalah proses pemberian bantuan yang diberikan kepada seseorang atau sekelompok orang secara terus menerus dan sistematis oleh pembimbing agar individu atau sekelompok individu menjadi pribadi yang mandiri.

Kedua, memberi nasihat. Nasihat merupakan suatu petunjuk yang membuat pelajaran dapat diterima dengan baik dari pemberi nasihat yang bisa digunakan sebagai referensi bagi penerima nasihat untuk mengerjakan sesuatu (Prayitno, 2011). Ketiga, memberi motivasi. Motivasi merupakan dorongan dari dalam diri seseorang untuk berusaha mengubah tingkah laku kearah yang baik dalam memenuhi kebutuhannya (Hamzah, 2013:3). Motivasi juga dapat berasal dari luar diri seseorang. Keluarga merupakan salah satu lingkungan yang dapat menumbuhkan motivasi siswa dalam belajar.

Keempat, memenuhi kebutuhan anak. Orang tua yang perhatian akan selalu memperhatikan fasilitas belajar anak sehingga proses belajar anak dapat berjalan secara obtimal. Fasilitas belajar yang harus ada yaitu: alat tulis, buku penunjang tematik, dan suasana belajar yang nyaman. Kelima, melakukan pengawasan. Menurut Atmosudirdjo (Febriani, 2005: 11) pengawasan adalah keseluruhan dari pada kegiatan yang membandingkan atau mengukur apa yang sedang atau sudah dilaksanakan dengan kriteria, normanorma, standar atau rencana-rencana yang telah ditetapkan sebelumnya.

\section{Hasil Belajar}

Hasil Belajar merupakan kemampuankemampuan yang dimiliki siswa setelah siswa menerima pengalaman belajarnya. Hasil belajar didapatkan dari individu yang belajar, baik mengenai pengetahuan, ataupun kemampuan untuk membentuk kecakapan dalam bersikap. Hasil belajar dapat diperoleh siswa setelah proses pembelajaran dalam kurun waktu tertentu yang diukur dengan menggunakan alat evaluasi yang tepat (Sudjana, 2013: 22). 
Menurut Jihad (2012: 14) hasil belajar merupakan pencapaian dalam bentuk perubahan perilaku yang cenderung menetap dari ranah kognitif, afektif, dan psikomotoris dari proses belajar yang dilakukan dalam waktu tertentu. Memperoleh hasil belajar dalam bentuk perubahan harus melewati proses tertentu yang akan di pengaruhi faktor yang berasal dari dalam diri maupun dari luar diri (Djamarah, 2011: 175). Menurut Slameto (2015: 54-72) faktor-faktor global dapat diuraikan dalam dua bagian yaitu: 1) Faktor yang berasal dari diri sendiri (internal) meliputi faktor jasmaniah dan faktor psikologis, 2)

Faktor yang Berasal Dari Luar Diri (Eksternal) meliputi Faktor lingkungan keluarga,

\section{METODE PENELITIAN}

Penelitian ini menggunakan metode kuantitatif jenis korelasi dan ex post facto. Korelasi merupakan suatu strategi penelitian untuk mengetahui hubungan dan tingkat hubungan antara dua variabel atau lebih tanpa adanya usaha untuk mempengaruhi variabel tersebut (Faenkel, 2008: 328). Sedangkan menurut Sappaile (2010: 105) ex post facto meneliti hubungan sebab akibat yang

\section{HASIL DAN PEMBAHASAN Uji Korelasi}

Hasil uji korelasi pengaruh peran orang tua terhadap hasil belajar tematik siswa menggunakan bantuan SPSS versi 21 dapat dilihat pada tabel 1 . Berdasarkan tabel output tersebut, diketahui jika nilai $r_{\text {hitung }}$ untuk hubungan peran orang tua $(X)$ dengan hasil belajar (Y) adalah sebesar 0.389 yang
Faktor lingkungan sekolah, Faktor lingkungan masyarakat.

\section{Pembelajaran Tematik \\ Menurut Kemendikbud pembelajaran tematik tidak memisahkan satu pelajaran dengan lainnya melainkan menggabungkan pelajaran- pelajaran tersebut dalam satu tema (Alimuddin, 2018: 262). Dalam kurikulun 2013 segala proses pembelajaran menjadikan murid sebagai pusatnya bukan guru. Siswa SD umumnya merasa ingin tahu segalanya dan membutuhkan bantuan benda konkret atau hal-hal yang dekat dengan lingkungannya untuk mendapatkan suatu pengertian (Kurniaman, \& Noviana, 2017).}

tidak dimanipulasi atau tidak diberi perlakuan oleh peneliti. Penelitian sebab akibat dilakukan terhadap kejadian yang telah terjadi.

Teknik pengumpulan data yang digunakan: 1) Angket dengan skala likert yaitu peran orang tua 2) Dokumentasi untuk hasil belajar tematik. Teknik analisis data yang digunakan yaitu uji korelasi, uji t dan uji determinasi.

berarti $>\mathrm{r}_{\text {tabel }}$ 0.349, maka dapat disimpulkan bahwa ada korelasi antara variabel peran orang tua dengan variabel hasil belajar. Kemudian berdasarkan pedoman derajat hubungan nilai pearson correlation 0.389 masuk pada tingkat hubungan rendah.

Tabel 1. Uji Korelasi

\begin{tabular}{|c|c|c|c|}
\hline \multicolumn{4}{|c|}{ Correlations } \\
\hline & & Peran Orang Tua & Hasil Belajar \\
\hline \multirow{4}{*}{ Peran Orang Tua } & Pearson Correlation & 1 & $.389^{*}$ \\
\hline & Sig. (2-tailed) & & .028 \\
\hline & $\mathrm{N}$ & 32 & 32 \\
\hline & Pearson Correlation & $.389^{*}$ & 1 \\
\hline \multirow[t]{2}{*}{ Hasil Belajar } & Sig. (2-tailed) & .028 & \\
\hline & $\mathrm{N}$ & 32 & 32 \\
\hline
\end{tabular}


Uji t

Hasil uji $t$ pengaruh peran orang tua terhadap hasil belajar tematik siswa menggunakan bantuan SPSS versi 21 dapat dilihat pada tabel 2 . Berdasarkan tabel output tersebut diketahui nilai $t_{\text {hitung }}$ sebesar $2.310>t_{\text {tabel }} 2.042$, sehingga dapat disimpulkan bahwa variabel peran orang tua $(\mathrm{X})$ berpengaruh terhadap variabel hasil belajar (Y) sebagaimana dasar pengambilan keputusan yang telah ditetapkan.

Tabel 2. Uji t

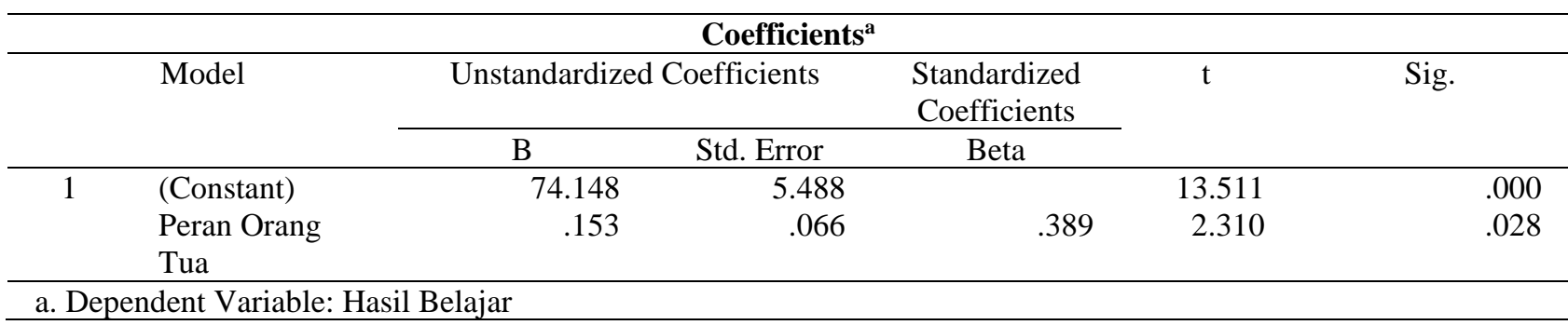

\section{Uji Koefisien Determinasi}

Hasil uji koefisien determinasi pengaruh peran orang tua terhadap hasil belajar tematik siswa menggunakan bantuan SPSS versi 21 dapat dilihat pada tabel 3. Berdasarkan tabel output tersebut besarnya nilai korelasi yaitu sebesar 0.389.
Nilai koefisien determinasi sebesar 0.151, yang mengandung pengertian bahwa pengaruh variabel peran orang tua $(\mathrm{X})$ terhadap variabel hasil belajar tematik (Y) adalah sebesar $15,1 \%$.

Tabel 3. Uji Koefisien Determinasi

\begin{tabular}{lcccr}
\hline \multicolumn{5}{c}{ Model Summary } \\
\hline Model & $\mathrm{R}$ & \multirow{2}{*}{ R Square } & Adjusted R Square & Std. Error of the Estimate \\
\hline 1 & $.389^{\text {a }}$ & .151 & .123 & 4.046 \\
\hline \multicolumn{2}{l}{ a. Predictors: (Constant), Peran Orang Tua } & & \\
\hline
\end{tabular}

Hasil penelitian menggunakan analisis korelasi product moment menunjukan ada pengaruh antara peran orang tua $(\mathrm{X})$ dengan hasil belajar tematik (Y) yaitu sebesar 0.389 dengan tingkat pengaruh rendah sesuai tabel koefisien korelasi menurut Sugiyono (2012: 231). Koefesien korelasi bernilai positif yang berarti terdapat hubungan yang positif. Berdasarkan uji t nilai thitung lebih besar dari ttabel yaitu $2.310>2.042$, maka ada korelasi antara peran orang tua terhadap hasil belajar tematik siswa. Kemudian berdasarkan uji determinasi menunjukan bahwa terdapat 15,1\% pengaruh peran orang tua terhadap hasil belajar tematik siswa.
Pada penelitian ini menunjukan pengaruh yang rendah antara peran orang tua terhadap hasil belajar siswa berbeda dengan penelitian terdahulu yang menunjukan pengaruh kuat. Hasil penelitian yang berbeda dapat dipengaruhi oleh faktor lain salah satunya adalah motivasi belajar siswa itu sendiri. Berdasarkan pengamatan peneliti selama melakukan observasi kebanyakan siswa memiliki semangat belajar yang tinggi dengan tujuan mendapatkan peringkat atas. Meski demikian berdasarkan koefisien regresi pada uji $\mathrm{t}$ jika kenaikan $1 \%$ nilai peran orang tua maka nilai hasil belajar siswa akan meningkat sebesar 0.153.

Peran orang tua sebagai salah satu faktor pendukung meningkatnya hasil belajar tematik 
siswa, hal ini dikarenakan anak belajar untuk pertama kalinya dari kedua orang tua. Nasution (1986: 42) mengatakan amatlah besar peranan orang tua dalam rumah tangga dalam usahanya untuk meningkatkan hasil belajar anak di sekolah. Karena tanpa adanya orang tua akan sulit dibayangkan bagaimana kelak pertumbuhan dan perkembangan intelek seorang anak. Jadi bagaimanapun dan apapun sikap orang tua terhadap anaknya tidaklah boleh melalaikan mengasuh dan memberikan bimbingan kepada mereka, sehingga dalam pendidikanya dapat dicapai hasil yang baik.

Ada beberapa penelitian yang mendukung hasil penelitian ini. Penelitian yang dilakukan oleh Eliyana Koyimah (2016) menunjukan bahwa terdapat hubungan perhatian orang tua dengan hasil belajar siswa, hal ini ditunjukan dengan koefisien korelasi sebesar $0.72>\mathrm{r}_{\text {tabel }} 0.213$ dan taraf signifikansi $0.000<0.05$ dengan tingkat hubungan kuat. Koefisieni $\left(\mathrm{r}^{2}\right)$ sebesar 56,6\%, sehingga perhatian orang tua berpengaruh atau meberikan sumbangan sebesar $56,6 \%$. Penelitian Cindy Pramedita (2017) menunjukkan bahwa terdapat hubungan positif dan signifikan antara bimbingan orang tua dengan prestasi belajar IPS dengan koefisien korelasi sebesar 0.476 lebih besar dari $r_{\text {tabel }} 0.161$. Hal ini berarti semakin

\section{SIMPULAN DAN REKOMENDASI}

Berdasarkan hasil penelitian dapat disimpulkan bahwa terdapat pengaruh peran orang tua terhadap hasil belajar tematik siswa kelas V MI Al-Ma'arif Merauke. Hasil tersebut dibuktikan dengan nilai thitung (2.310) > ttabel (2.042). Hasil perhitungan korelasi diketahui terdapat hubungan dengan tingkat korelasi rendah (0.20-0.399). Besarnya pengaruh peran orang tua terhadap hasil belajar tematik siswa sebesar $15.1 \%$.

Berdasarkan hasil penelitian sebagaimana telah diuraikan dalam simpulan tersebut, maka peneliti menyampaian beberapa saran yaitu: 1) Mengingat peran orang tua terhadap hasil belajar tinggi peran orang tua dalam membimbing anak dalam belajar akan semakin tinggi pula prestasi belajar anaknya.

Selain itu, penelitian yang dilakukan oleh McNeal Jr (2014: 564) menunjukkan bahwa keterlibatan orang tua dalam mendampingi anaknya mempengaruhi sikap dan perilaku siswa sehingga secara tidak langsung memberikan pengaruh bagi prestasi siswa. Orang tua yang secara intens terlibat dalam mendapingi anaknya akan memberikan dampak yang positif bagi perkembangan anknya di sekolah dan dalam hidup masyarakat.

Setiap proses belajar anak diperlukan adanya peran orang tua yang akan meningkatkan hasil belajar anak. Adanya peran orang tua dapat diketahui dengan adanya indikator yang meliputi memberi bimbingan, memberi nasihat, memberi motivasi, dan melakukan pengawasan.

Proses belajar membutuhkan kerjasama antara guru, pihak sekolah dan orang tua. Adanya komunikasi antara pihak guru, sekolah dan orang tua perkembangan pembelajaran anak dapat terkontrol. Pihak sekolah bertanggung jawab untuk kegiatan belajar di sekolah sedangkan peran orang tua dibutuhkan untuk membantu proses belajar anak di rumah.

tematik siswa sangat penting, maka orang tua perlu menjalankan perannya dengan baik sebagai bagian dari kewajiban orang tua terhadap pendidikan anak. tidak berarti peran orang tua tidak diperlukan untuk meningkatkan hasil belajar siswa. Meskipun sedikit peran orang tua sangat diperlukan oleh anak sebagai bagian dari kewajiban orang tua. 2) Semoga sekolah selalu mengingatkan orang tua pentingnya peran mereka terhadap anak sehingga siswa lebih mawas dalam belajar karena orang tua merupakan salah satu faktor yang mempengaruhi siswa. 


\section{PRIMARY: JURNAL PENDIDIKAN GURU SEKOLAH DASAR \\ VOLUME 9 NOMOR 4 AGUSTUS 2020 \\ ISSN: 2303-1514 | E-ISSN: 2598-5949 \\ DOI : http://dx.doi.org/10.33578/jpfkip.v9i4.7986 \\ https://primary.ejournal.unri.ac.id/index.php/JPFKIP}

\section{UCAPAN TERIMA KASIH (OPTIONAL)}

Ucapakan terima kasih ditujukan kepada sekolah MI AL-Ma'arif dan siswa Kelas V yang bersedia menjadi responden dalam penelitian ini.

\section{DAFTAR PUSTAKA}

Alimuddin J. (2018). Optimalisasi Peran Orang Tua Dalam Pembelajaran Tematik Integratif di Sekolah Dasar. Prosiding Seminar Nasional. Universitas Muria Kudus: Kudus.

Arifin. (2012). Pokok-pokok Pemikiran Tentang Bimbingan dan Penyuluhan Agama. Jakarta: Bulan Bintang

Cindy P. (2017). Hubungan Bimbingan Orang Tua Dengan Prestasi Belajar IPS Pada Siswa Kelas IV SD Negeri. Skripsi. Tidak Diterbitkan. Fakultas Keguruan dan Ilmu Pendidikan. Universitas Lampung: bandar lampung.

Daradjat. (2004). Ilmu Pendidikan Islam. Jakarta: Grafindo.

Djamarah, S. B. (2011). Psikologi Belajar. Jakarta: PT. Rineka Cipta.

Eliyana K. (2016). Hubungan Perhatian Orang Tua Dengan Hasil Belajar IPS Pada Siswa Kelas $\mathrm{V}$ SDN di gugus Ki Hajar Dewantara Kabupaten Semarang. Skripsi. Tidak Diterbitkan. Fakultas Ilmu Pendidikan. Universitas Negeri Semarang: Semarang.

Frankel, J. P., \& Wallen N. E. (2018). How to Design and Evaluatte Reserch in Education. New York: Mc Graw-Hill Companies, inc.

Fredy, F., Tembang, Y., \& Purwanty, R. 2019. Analisis Kepuasan Orangtua dan Siswa terhadap Kualitas Layanan Pendidikan Dasar. Musamus Journal of Primary Education, 59-66.

Hamzah. B. U. (2013). Teori Motivasi dan Pengukurannya. Jakarta: PT. Bumi Aksara.

Hasbullah. (2011). Dasar-Dasar Ilmu Pendidikan. Jakarta: Rajawali Pers.

Hurit, A. A., \& Harmawati, D. (2019). Analisis Kesiapan Guru dalam Mengimplementasikan Kurikulum 2013 di SD Inpres Gudang Arang Merauke.
Musamus Journal of Primary Education, 116-123.

Jihad, Asep, \& Haris, A. (2012). Evaluasi Pembelajaran. Yogyakarta: PT. Bumi Aksara.

Kurniaman, O., \& Noviana, E. (2017). Penerapan Kurikulum 2013 dalam meningkatkan keterampilan, sikap, dan pengetahuan. Primary: Jurnal Pendidikan Guru Sekolah Dasar. 6(2), 389-396.

McNeal Jr, R. B. (2014). Parent Involvement, Academic Achievement and the Role of Student Attitudes and Behaviors as Mediators. Universal Journal of Educational Research. 2(8), 564-576.

Muchuchuti, N. (2015). The Influence of Parental Involvement on the Learning outcomes of their Children: A Case study of Primary School Children in Matabeleland Regions. IOSR Journal of Research \& Method in Education (IOSR-JRME). 5 (6), 25-32.

Prastowo, A. (2014). Panduan Kreatif Membuat Bahan Ajar Inovatif. Yogyakarta: Diva Press.

Prayitno. (2011). Panduan Panduan Bagi Penyelenggara Program Penerapan Belajar Kegiatan Pengawasan Bimbingan dan Konseling di Sekolah. Jakarta: PT. Rineka Cipta.

Purnamie, T. (2014). Peranan Oraganizational Citizenship Behavior. Bandung: Mitra Wacana Media.

Purwanto. (2013). Evaluasi Hasil Belajar. Yogyakarta: Pustaka Belajar.

Reni A. \& Huwadi. (2004). Psikologi Perkembangan Anak Mengenal Sifat,

Bakat, dan Kemampuan Anak. Jakarta: Grasindo.

Sapaile, B. I. (2010). Konsep Penelitian Ex-Post Facto. Jurnal Pendidikan Matematika. 1(2), 105. 
Slameto. (2010). Belajar dan Faktor-Faktor yang Mempengaruhinya. Jakarta: PT. Bumi Aksara.

Sugiyono. (2016). Metode Penelitian Kuantitatif, Kualitatif dan $R \& D$. Bandung: Alfabeta.

Sukardi, Ketut D., \& Kusumawati, N. (2008). Proses Bimbingan dan Konseling di Sekolah. Jakarta: PT. Rineka Cipta.

Wahy, Hasbi. (2012). Keluarga Sebagai Basis Pendidikan Pertama dan Utama. Jurnal Ilmiah DIDAKTIKA, 12(2), 245-258. 